\title{
nature
} cell biology

\section{Draining resources}

The Association of

University Teachers (UK)

believes that jobs for

academics in the UK are

far less secure than for

bar staff $\rightarrow$ i cientists by their own nature often move around in the courses of their careers, changing labs during their post-doctoral years before settling down as independent researchers. This constant ebb and flow of highly qualified scientists in countries like the UK, Germany or Australia was usually buffered by incoming recruits, often from the US and Europe, with most post-doctoral scientists returning to their country of origin to start their own labs.

Recently, however, that is all changing. As funding for science in the UK continues to plummet, more and more talented scientists are leaving but not returning. In December 1999 the Association of University Teachers (UK) claimed that jobs for academics in the UK are far less secure than for bar staff and has backed a claim for a 30\% pay increase over the next four years. This, they argue, will bring the pay of UK academics into line with that of their overseas counterparts, and without it the loss of high-calibre academics from UK universities to the US will continue, causing education in British universities to slide down the international ladder.

Recent figures from the Royal Society, London, confirm that record numbers of British academics are heading overseas in a 'brain-drain' that could seriously damage British research. Over a quarter of Royal Society fellows are now based outside the UK, as compared to less than one-fifth 20 years ago. In January the Vice-president of the Royal Society, Professor John Enderby, said that many academics were being lured to the US by bigger pay packets and easier access to research funding and equipment.

If the ebb and flow becomes simply an ebb, the UK could lose its brightest stars to foreign countries, particularly the US. The Bett report into Higher Eduction and Pay found that problems are already apparent within the UK university system. Lack of career development and uncompetitive salaries are making it far more difficult for UK universities to recruit and retain the best scientists, especially in core research areas such as biology. British vicechancellors confirmed this worrying trend, saying that it is incredibly difficult to recruit highcalibre professors and senior academics. One lab head who left for the US, after actively deciding to return to the UK following a previous post-doc in the States, said that they had never considered a permanent move to the US until the funding situation in Britain made it "the only sensible option".

To compensate for this lack of funding, the Bett report propsoses that UK universities will have to rely on other financial sources in order to increase pay and retain scientists. It seems, however, that increased private funding is exacerbating previous tensions in the lab. It is now possible to walk into many UK labs where the university-employed lab head is paid less than his or her privately funded post-doc. How this will affect the already low morale of lab heads is yet to be seen.

\section{The future}

So, how will the future of British science shape up? As a nation that always attracted highquality scientists, it is in dire need of a new direction and a fresh impetus to encourage homegrown, high-quality academics to stay. The days when the UK was the paragon of academic excellence are over, it seems, and unless funding problems, increasing administrative loads and the poor public perception of academics are changed, the future is bleak. With the average age of UK academics increasing and the brightest hopes for the future leaving the country, the outcome of the current 'brain-drain' could be felt for many generations to come. 